\title{
Pengaruh Kreatifitas dalam bekerja terhadap kebermaknaan hidup
}

\author{
Rahmat Aziz \\ Psikologi, Universitas Islam Negeri Malang, Indonesia \\ Email: azira@uin-malang.ac.id \\ Retno Mangestuti \\ Psikologi, Universitas Islam Negeri Malang, Indonesia \\ Email: mangestuti@uin-malang.ac.id
}

(Diterima: 13-Oktober-2018; direvisi: 122-November-2018; dipublikasikan: 29-Desember-2018)

\begin{abstract}
This study aimed to examine the direct effect of creativity on the meaning of life, and an indirect effect through performance. Subjects were 186 teachers (113 male and 73 female). The data were collected by the creativity scale, the job performance scale, and the meaning in life scale. The data were analyzed by moderated regression analysis. The results showed that performance play a role in strengthening the relationship between creativity and the search for a meaningful life ( $<<.01)$, but not in the relationship between creativity and the presence of meaning of life ( $p>.05)$.
\end{abstract}

Keyword: Creativity; meaning in life; performance

\begin{abstract}
Abstrak. Penelitian ini bertujuan untuk menguji pengaruh kreativitas terhadap pencarian dan kehadiran makna hidup, dengan menjadikan kinerja sebagai variabel moderator. Subjek penelitian berjumlah 186 guru Madrasah Ibtidaiyah (113 laki-laki dan 73 perempuan). Data diperoleh melalui skala kreativitas, kinerja dan hidup bermakna. Analisis data dilakukan melalui analisis regresi dengan moderator. Hasil analisis menunjukkan bahwa kinerja mampu berperan utuk memperkuat hubungan antara kreativitas dengan pencarian makna hidup ( $\mathrm{p}<.01$ ), tapi tidak pada hubungan antara kreativitas dengan kehadiran makna hidup $(\mathrm{p}>.05)$.
\end{abstract}

Kata kunci: Kinerja; kreativitas; hidup bermakna

Copyright (C) 2018 Universitas Negeri Makassar. This is an open access article under the CC BY-NC-ND license (http://creativecommons.org/licenses/by-nc-nd/4.0/).

\section{PENDAHULUAN}

Kajian tentang hidup bermaka merupakan kajian yang sangat penting dan strategis untuk dilakukan, seiirng dengaan berkembangnya psikologi positif. Hal ini didasari anggapan bahwa pada dasarnya setiap manusia mempunyai hasrat untuk hidup bermakna, hanya saja tidak semua orang mampu mendapatkannya. Bagi orang yang menemukan, orang tersebut akan mengembangkan perilaku sehat dalam kehidupannya (Steger, Fitch-Martin, Donnelly, \& Rickard, 2015) dan mampu mendapatkan kebahagiaan (Cohen \& Cairns,
2012), sedangkan bagi yang tidak mendapatkannya, orang tersebut akan mengalami kehampaan eksistensial yang pada gilirannya dapat mengalami gangguan psikologis (Dezutter, Luyckx, \& Wachholtz, 2015).

Manusia memiliki keinginan yang kuat untuk memahami diri sendiri dan dunia di sekitar mereka yang ditunjukkan dengan aktivitas kognitif dan perilaku untuk mendukung keinginan tersebut (de Souza, Francis, O'Higgins-Norman, \& Scott, 2009). Hal ini berarti bahwa manusia secara teoritis mengalami 
kehadiran makna ketika mereka memahami diri mereka sendiri dan dunianya.

Makna hidup sebagai suatu konsep psikologis dapat didefinisikan dengan berbagai cara. Stegar et al. (2006) telah memberikan penjelasan tentang perbedaan dalam mendefinisikan makna hidup. Mereka menjelaskan bahwa makna hidup dapat dipahami dari aspek pencarian makna dan kehadiran makna. Selanjutnya Steger et al., (2008) menjelaskan adanya hubungan yang sangat erat antara kedua jenis makna hidup tersebut.

Pencarian makna hidup oleh setiap manusia dilakukan dalam berbagai kehidupan, termasuk dalam bekerja. Hasil penelitian menunjukkan bahwa pada dasarnya setiap orang yang bekerja adalah sedang mencari makna dalam pekerjaannya (Finch, 1997). Hal ini menunjukkan bahwa ada hubungan antara kinerja dengan proses penemuan dan kehadiran makna dalam hidupnya.

Di Indonesia, penelitian yang mengkaji tentang kinerja guru telah dilakukan. Misalnya penelitian Ekosusilo \& Soepardjo (2014) dan Raddana (2014) meneliti tentang faktor-faktor yang berpengaruh terhadap kinerja guru. Hasil penelitiannya menemukan bahwa motivasi, kepuasan kerja, budaya organisasi, kepemimpinan kepala sekolah berpengaruh terhadap kinerja guru. Penelitian sejenis dan menarik untuk dicermati telah dilakukan oleh Ilmawan dan Noermijati (2016) yang menemukan bahwa kinerja guru banyak dipengaruhi oleh faktor kompensasi, kepemimpinan dan kepuasan kerja. Tapi apakah kinerja tersebut dapat meningkatkan makna hidup guru tersebut? Beberapa penelitian diatas ternyata belum mampu menjawab pertanyaan ini, sehingga penting untuk dicari jawaban empirik tentang pengaruh kinerja terhadap hidup bermakna.

Banyak faktor yang dapat diduga menjadi penyebab tinggi rendahnya kinerja guru, baik yang sifatnya internal maupun eksternal. Diantara faktor internal yang diduga menjadi penyebab rendahnya kinerja guru adalah kreativitas. Penelitian yang menguji kreativitas dengan kinerja telah dilakukan Mardiyoko, Joyoatmojo, \& Suryani, (2013) yang menemukan adanya hubungan antara kreativitas dengan kinerja guru. Penjelasan mengapa terdapat hubungan antara keduanya, telah dijelaskan oleh Sawyer (2004) yang menyatakan bahwa kreativitas menjadi inti dalam pelaksanaan proses pembelajaran sebagai tugas utama seorang guru, karena dengan kreativitas akan ditemukan sesuatu yang baru dan inovatif. Bahkan dia menyatakan bahwa mengajar itu lebih merupakan suatu seni dan kreativitas dari guru tersebut.

Kreativitas sebagai sebuah konstruk psikologis dapat diartikan dari berbagai pendekatan. Rhodes (1961) berdasarkan kajian terhadap 40 definisi tentang kreativitas menyimpulkan bahwa pada umumnya kreativitas didefinisikan sebagai pribadi (person), proses (process), produk (product), dan pendorong (press). Sebagai pribadi (person) kreativitas diartikan sebagai karakteristik kepribadian non kognitif yang melekat pada orang kreatif.

Kreativitas pada penelitian ini didefinisikan sebagai karakteristik kepribadian yang bersifat non-kognitif. Menurut Sternberg dan Lubart (1995) ada enam karakteristik dari kepribadian kreatif yaitu ketekunan dalam menghadapi tantangan, keinginan untuk selalu berkembang, keberanian untuk menanggung resiko, toleransi terhadap ambiguitas, keterbukaan terhadap pengalaman baru dan keteguhan terhadap pendirian.

Pentingnya kreativitas dalam kehidupan sudah banyak dikaji oleh para ahli. Diantaranya adalah Matheson (2016) yang menyatakan bahwa kreativitas berhubungan dengan hidup bermakna. Dia menjelaskan bahwa pada dasarnya kegiatan kreatif adalah kegiatan yang bertujuan untuk mencapai sesuatu yang bernilai dan bermakna dalam kehidupan. Namun demikian, penelitian yang dikemukakan oleh Kyaga (2015) yang menyatakan bahwa banyak ditemukan orang yang sakit mental tapi ternyata menghasilkan karya yang kreatif. Hasil penelitian di atas menarik untuk dikaji lebih lanjut tentang hubungan antara kreativitas dan hidup bermakna.

Untuk memahami dinamika hidup bermakna pada kehidupan seorang guru, digunakan teori logoterapi sebagai perspektif analisis. Landasan filosofis aliran ini dibangun atas asumsi bahwa manusia pada dasarnya mempunyai kebebasan untuk berkehendak (freedom of will), kehendak untuk hidup bermakna (will to meaning), dan makna hidup (meaning of life). Artinya setiap guru berusaha untuk mendapatkan makna dalam hidupnya. Usaha yang dapat dilakukan adalah dengan bekerja secara baik dan benar sesuai dengan kriteria yang telah ditentukan. Untuk 
memperjelas dibuat sebuah gambar sebagai

berikut:

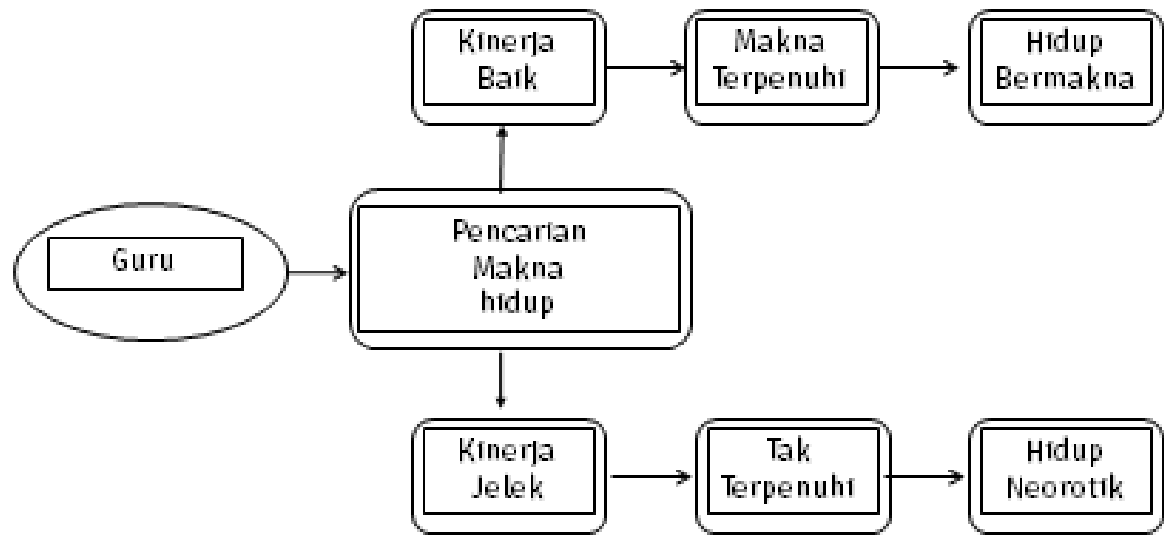

Gambar 1. Proses pencarian makna hidup

Penjelasan gambar diatas adalah sebagai berikut: Seorang guru dalam melaksanakan tugasnya pada dasarnya adalah sedang dalam proses pencarian makna dalam hidupnya. Bagi guru yang bekerja secara baik maka makna hidup akan ditemukan, dan sebaliknya.

\section{METODE}

Subjek penelitian berjumlah 186 guru Madrasah Ibtidaiyah (laki-laki 113 dan perempuan 73 orang) yang berasal dari empat kabupaten di Jawa Timur yaitu kabupaten Kediri, Magetan, Trenggalek dan Probolinggo. Data ini diambil ketika subjek mengikuti kegiatan sertifikasi guru yang diselenggarakan oleh fakultas Ilmu Tarbiyah dan Pendidikan Universitas Islam Negeri Malang. Perincian subjek penelitian berdasarkan asal daerah dan jenis kelamin dapat di lihat pada tabel 1 di bawah ini:

Tabel 1. Subjek penelitian

\begin{tabular}{|c|c|c|c|c|c|c|c|}
\hline \multirow{3}{*}{$\mathbf{N}$} & \multirow{3}{*}{ Asal Daerah } & \multicolumn{6}{|c|}{ Jenis Kelamin } \\
\hline & & \multicolumn{2}{|c|}{ Laki-laki } & \multicolumn{2}{|c|}{ Perempuan } & \multicolumn{2}{|c|}{ Jumlah } \\
\hline & & $\mathbf{F}$ & $\%$ & $\mathbf{F}$ & $\%$ & $\mathbf{F}$ & $\%$ \\
\hline 1 & Kediri & 30 & 16,13 & 20 & 10,75 & 50 & 26,88 \\
\hline 2 & Magetan & 22 & 11,83 & 18 & 9,68 & 40 & 21,51 \\
\hline 3 & Trenggalek & 26 & 13,98 & 18 & 9,68 & 44 & 23,66 \\
\hline 4 & Probolinggo & 35 & 18,82 & 17 & 9,14 & 52 & 27,96 \\
\hline \multicolumn{2}{|c|}{ Jumlah } & 113 & 60,75 & 73 & 39,25 & 186 & 100 \\
\hline
\end{tabular}

Tiga alat ukur yang digunakan pada penelitian ini adalah alat ukur The Meaning in life Questionnaire, skala kreativitas, dan skala kinerja guru. Penjelasan ketiga alat ukur tersebut adalah sebagai berikut: (1) Pengukuran makna hidup dilakukan melalui alat ukur The Meaning in Life Questionnaire (MLQ) yang telah dibuat dan diuji reliabilitasnya oleh Steger et al., (2006).
Alat ukur ini mampu mengungkap aspek makna hidup dilihat dari pencarian makna dan kehadiran makna. Alat ukur MLQ telah dilakukan uji coba pada 154 orang dewasa yang hasilnya menunjukkan bahwa aspek pencarian makna hidup menunjukkan nilai $\alpha=.87$ dan aspek kehadiran makna hidup nilai $\alpha=.82$. Beberapa contoh item yang digunakan 
diantaranya adalah: (1) Saya selalu mencari sesuatu yang membuat hidup saya penuh arti; dan (2) Saya sangat mengerti tentang makna kehidupan saya; (2) Pengukuran kinerja guru yang digunakan pada penelitian ini berupa skala pengukuran kinerja guru yang telah dibuat oleh Kementrian Pendidikan Nasional yang digunakan untuk menentukan penilaian sertifikasi guru. Alat ukur ini mampu mengungkap kompetensi kinerja guru pada aspek pedagogik dan profesional. Alat ukur ini diuji coba pada 110 guru Madrasah Ibtidaiyah yang sedang mengikuti program sertifikasi guru di di Fakultas Ilmu Tarbiyah dan Keguruan Universitas Islam Negeri (UIN) Malang. Hasil uji coba tersebut menunjukkan bahwa skala kinerja guru pada aspek pedagogik memperoleh nilai $\alpha=.78$ dan aspek profesional memperoleh nilai $\alpha=.72$. Beberapa contoh item yang digunakan diantaranya adalah: (1) Kemampuan menghidupkan suasana kelas, dan (2) Saya mampu menjelaskan keterkaitan pokok bahasan dengan konteks kehidupan; (3) Pengukuran kreativitas guru yang digunakan pada penelitian ini berupa skala likert tentang skala kepribadian kreatif yang disusun penulis dengan mengacu pada teori yang dikemukakan oleh Sternberg dan Lubart (1995). Skala ini bentuknya berupa perntaan yang dapat menggambarkan kondisi subjek. Jumlahnya sebanyak 48 item yang bersifat favorable dan unfavorable, namun setelah dilakukan uji coba pada 110 guru
Madrasah Ibtidaiyah yang sedang mengikuti program sertifikasi guru di di Fakultas Ilmu Tarbiyah dan Keguruan UIN Malang ditemukan ada sebanyak 17 item yang valid. Hasil uji coba tersebut menunjukkan bahwa skala kreativitas memperoleh nilai $\alpha=.80$. Beberapa contoh item yang digunakan diantaranya adalah: (1) Mengerjakan tugas sampai tuntas, (2) Berani menanggung akibat perbuatan sendiri, (3) Tidak berani berbeda dengan orang lain $(R)$, (4) Merasa sudah cukup sempurna (R), (5) Menyukai banyak alternatif jawaban, dan (6) Konsisten dengan apa yang sudah diucapkan

Analisis data dilakukan dengan menggunakan analisis regresi dengan moderator yang bertujuan untuk menguji hubungan variabel bebas (kreativitas) dan variabel terikat (hidup bermakna: pencarian dan kehadiran makna hidup) dengan menjadikan varibel kinerja sebagai variabel moderator.

\section{HASIL DAN PEMBAHASAN}

Hasil pengujian normalitas dan linearitas terhadap variabel yang diuji menunjukkan bahwa semua variabel mempunyai data yang normal dan hubungan antar variabel yang diuji adalah linear. Hasil analisis deskriptif dan korelasional variabel yang diuji pada penelitian iini dapat dilihat pada tabel 2 di bawah ini.

Tabel 2. Interkorelasi antar variabel

\begin{tabular}{llllllll}
\hline $\mathbf{1}$ & Variabel & Mean & SD & $\mathbf{1}$ & $\mathbf{2}$ & $\mathbf{3}$ & $\mathbf{4}$ \\
\hline 1 & Kreativitas & 68.3 & 8.7 & - & & & \\
2 & Kinerja & 158.5 & 19.7 & .431 & - & & \\
3 & Pencarian makna hidup & 21 & 2.9 & .537 & .302 & - & \\
4 & Kehadiran makna hidup & 17.6 & 3 & .356 & .290 & .325 & - \\
\hline
\end{tabular}

Hasil analisis regresi tentang kreativitas dan pencarian kebermaknaan hidup ditemukan $\mathrm{R}^{2}=.537 \mathrm{p}<.01$. Artinya $53,7 \%$ pencarian kebermaknaan hidup dipengaruhi oleh kreativitas. Hasil analisis kreativitas dengan kinerja sebagai variabel moderator ditemukan $\mathrm{R}^{2}$ $=.564 \mathrm{p}<.01$. Artinya 56,4\% kontribusi interaksi kinerja sebagai moderator dan kreativitas terhadap pencarian kebermaknaan hidup, ada peningkatan sumbangan efektif sebesar $2,7 \%$. Hasil ini menunjukkan bahwa kinerja mampu menjadi variable moderator yang memperkuat hubungan kreativitas dengan pencarian makna hidup. Hasil selengkapnya terlihat pada table 3 berikut ini.

Tabel 3. Hasil Pencarian Makna hidup

\begin{tabular}{llll}
\hline & $\mathrm{R}$ & $\mathrm{p}$ & Ket. \\
\hline Kreativitas & .526 & .000 & Sig. \\
Kinerja & .170 & .007 & Sig. \\
Moderator & -.002 & .012 & Sig. \\
\hline
\end{tabular}

Hasil analisis regresi tentang kreativitas dan kehadiran makna hidup ditemukan $\mathrm{R}^{2}$ $=.356 \mathrm{p}<.01$. Artinya 35,6\% kehadiran makna hidup dipengaruhi oleh kreativitas. Hasil analisis 
kreativitas dengan kinerja sebagai variabel moderator ditemukan $\mathrm{R}^{2}=.393 \mathrm{p}>.05$. Artinya peran kontribusi interaksi kinerja sebagai moderator dan kreativitas terhadap kehadiran makna hidup tidak signifikan,. Hasil ini menunjukkan bahwa kinerja tidak mampu menjadi variable moderator yang memperkuat hubungan kreativitas dengan kehadiran makna hidup. Untuk memperjelas hasil tersebut dapat dilihat pada table 4 di bawah ini.

Tabel 4. Hasil Pencarian Makna hidup

\begin{tabular}{llll}
\hline & $\mathrm{R}$ & $\mathrm{p}$ & Ket. \\
\hline Kreativitas & -.068 & .673 & Non sig. \\
Kinerja & -.047 & .508 & Non sig. \\
Moderator & .001 & -.301 & Non sig. \\
\hline
\end{tabular}

Dengan kata lain, hasil penelitian di atas menunjukkan bahwa kreativitas merupakan variabel yang penting sebagai pondasi untuk kebermaknaan hidup seorang guru, khususnya pada pencarian makna hidup. Untuk memperkuat hubungan tersebut diperlukan kinerja yang baik dalam menjalankan tugasnya sebagai seorang guru.

Hasil analisis yang menunjukkan bahwa kreativitas berpengaruh terhadap hidup bermakna adalah sejalan dengan penelitian yang telah dilakukan telah Matheson (2016) yang menyatakan bahwa kreativitas berhubungan dengan hidup bermakna. Dia menjelaskan bahwa pada dasarnya kegiatan kreatif adalah kegiatan yang bertujuan untuk mencapai sesuatu yang bernilai dan bermakna dalam kehidupan.

Hasil analisis yang menunjukkan bahwa kreativitas berpengaruh terhadap kinerja adalah sejalan dengan hasil penelitian Mardiyoko, Joyoatmojo, \& Suryani, (2013) yang menemukan adanya hubungan antara kreativitas dengan kinerja guru. Hubungan antara kreativitas dengan kinerja juga telah dijelaskan oleh Widhiastuti (2014) yang menyatakan bahwa kreativitas itu menjadi aspek yang sangat penting pada kinerja.

Penjelasan mengapa terdapat hubungan antara keduanya, telah dijelaskan oleh Sawyer (2004) yang menyatakan bahwa kreativitas menjadi inti dalam pelaksanaan proses pembelajaran sebagai tugas utama seorang guru, karena dengan kreativitas akan ditemukan sesuatu yang baru dan inovatif. Bahkan dia menyatakan bahwa mengajar itu lebih merupakan suatu seni dan kreativitas dari guru tersebut.

Hasil penelitian yang menunjukkan adanya hubungan antara kinerja dengan hidup bermakna adalah sejalan dengan penelitian yang telah dilakukan oleh vaksalla \& Hashimmah (2015) yang menemukan adanya hubungan antara keterlibatan dalam bekerja dengan kehidupan yang bermakna. Demikian juga penelitian yang menemukan bahwa orang yang bekerja dengan baik ternyata mempunyai kesejateraan psikologis yang baik pula (Lin, Yu, \& Yi, 2014). Penelitian lain menemukan adanya hubungan antara kesejahteraan dengan kehidupan yang penuh makna (Steger, Kashdan, Sullivan, \& Lorentz, 2008). Hasil inipun dapat dijelaskan bahwa seorang guru yang sedang bekerja pada dasarnya adalah sedang berusaha untuk mendapatkan kebermaknaan dalam hidupnya (Finch, 1997).

Dalam konteks kehidupan seorang guru, salah satu upaya yang dapat dilakukan untuk menemukan makna hidup adalah dengan bekerja sebaik mungkin. Tugas utama seorang guru adalah mengajar dan mendidik siswa supaya mereka berkembang sesuai dengan potensinya. Karena itu tugas ini semestinya menjadi sesuatu yang sangat mulia dan membanggakan. Namun sayangnya beberapa penelitian menemukan bahwa banyak guru yang merasa tidak bermakna dan tidak berbahagia dalam kehidupannya.

Hasil survey yang dilakukan Smith (2007) terhadap dua belas profesi yang dianggap paling bahagia, ternyata profesi guru tidak termasuk didalamnya. Penelitian sejenis dilakukan Nor (2004) yang menemukan bahwa kepuasan guru terhadap profesinya hanya berada pada kategori sedang, bahkan hampir mendekati rendah. Kinerja seorang guru menurut Usman (2003) diartikan sebagai hasil kerja yang terlihat dari serangkaian kemampuan yang dimiliki oleh seorang yang berprofesi sebagai guru.

Logoterapi yang dibangun atas asumsi bahwa manusia pada dasarnya mempunyai kebebasan untuk berkehendak (freedom of will), kehendak untuk hidup bermakna (will to meaning), dan makna hidup (meaning of life). Hasil penelitian yang menunjukkan bahwa kinerja berpengaruh terhadap makna hidup seorang guru, dapat dijelaskan bahwa setiap guru berusaha untuk mendapatkan makna dalam hidupnya. Usaha yang dilakukan adalah dengan bekerja secara baik dan benar sesuai dengan kriteria yang telah ditentukan. Karena itulah 
ketika mereka mampu mewujudkan daya ciptanya berupa pelayanan terhadap orang lain maka secara bersamaan makna hidup akan meningkat karena perbuatan tersebut.

Hasil analisis yang menemukan bahwa kinerja tidak mampu berperan sebagai moderator pada hubungan antara kreativitas dan kehadiran makna hidup adalah hasil yang harus dicermati lebih lanjut. Ada beberapa kemungkinan yang dapat diduga menjadi penyebabnya, yang dapat dijadikan sebagai program penelitian lanjutan, sehingga ditemukan penjelasan yang lebih memadai.

Implikasi temuan penelitian yang menyatakan kinerja mampu menjadi variabel moderator pada hubungan antara kreativitas dan pencarian hidup bermakna. Hal ini dapat dipahami bahwa pencarian makna hidup seorang guru yang bekerja dengan sepenuh hati dan penuh kesungguhan sehingga makna hidup yang dicari oleh guru tersebut akan terpenuhi. Sebaliknya seorang guru yang ingin mencari makna hidup tapi tidak bekerja dengan sepenuh hati maka makna hidup yang dicarinyapun tidak akan tercapai, sekalipun guru tersebut adalah guru yang kreatif.

\section{SIMPULAN DAN SARAN}

Kinerja merupakan variabel yang penting untuk diperhatikan dan dikembangkan apabila individu ingin mendapatkan makna dalam hidupnya. Kreativitas memang merupakan variabel yang penting dalam hubungannya dengan makna hidup, tapi ketika pribadi kreatif dibarengi dengan kinerja yang baik maka makna hidup akan lebih mungkin untuk dapat dicapai oleh individu tersebut.

\section{DAFTAR RUJUKAN}

Cohen, K., \& Cairns, D. (2012). Is Searching for Meaning in Life Associated With Reduced Subjective Well-Being? Confirmation and Possible Moderators. Journal of Happiness Studies, 13(2), 313-331. https://doi.org/10.1007/s10902-011-9265-7

de Souza, M., Francis, L. J., O’Higgins-Norman, J., \& Scott, D. (Eds.). (2009). International Handbook of Education for Spirituality, Care and Wellbeing (Vol. 3). Dordrecht: Springer Netherlands. Retrieved from http://link.springer.com/ 10.1007/978-1-4020-9018-9
Dezutter, J., Luyckx, K., \& Wachholtz, A. (2015). Meaning in life in chronic pain patients over time: associations with pain experience and psychological well-being. Journal of Behavioral Medicine, 38(2), 384-396.

https://doi.org/ .1007/s10865-014-9614-1

Ekosusilo, M., \& Soepardjo, S. (2014). Faktor dominan yang mempengaruhi motivasi kerja, kinerja, dan kepuasan kerja guru SMA. Jurnal Ilmu Pendidikan, 20(2), 134-143.

Fegg, M. J., Kögler, M., Brandstätter, M., Jox, R., Anneser, J., Haarmann-Doetkotte, S., ... Borasio, G. D. (2010). Meaning in life in patients with amyotrophic lateral sclerosis. Amyotrophic Lateral Sclerosis, 11(5), 469-474.

Finch, G. L. (1997). The Quest for Meaning in Work. The Graduate School Cincinnati, Ohio, The Union Institute.

Ilmawan, M. D., \& Noermijati, N. (2016). Peran kompensasi dan karakteristik leadership pada kinerja guru yang dimediasi oleh kepuasan kerja. Jurnal Ekonomi Modernisasi, 12(2), 51-62.

Lin, Y.-C., Yu, C., \& Yi, C.-C. (2014). The Effects of Positive Affect, Person-Job Fit, and Well-being on Job Performance. Social Behavior and Personality: An International Journal, 42(9), 1537-1547.

Mardiyoko, T., Joyoatmojo, S., \& Suryani, N. (2013). Kontribusi Kompetensi Profesional Guru dan Kreativitas Guru terhadap Kinerja Guru Dalam Pembelajaran. Teknologi Pendidikan, 1(1), 1-10.

Matheson, D. (2016). Creativity and Meaning in Life. Ratio. https://doi.org/ 10.1111/rati.12153

Nor, M. R. B. M. (2004). Faktor-faktor Yang Mempengaruhi Kepuasan Kerja Guru Dalam Bidang Teknik Dan Vokasional Berdasarkan Teori Maslow Di Sekolah Akademik Di Daerah Pasir Puteh, Kelantan. Univeristy Teknik Malaya.

Raddana, H. M. (2014). Faktor-Faktor yang Mempengaruhi Kinerja Guru SMA Negeri. Jurnal Kependidikan, 13(2), 125-136. 
Smith, T. W. (2007). Job Satisfaction in The United State. Retrieved from http://citeseerx.ist.psu.edu/viewdoc/downloa $\mathrm{d}$ ?doi=10.1.1.546.6204\&rep=rep1\&type=pd $\mathrm{f}$

Steger, M. F., Fitch-Martin, A. R., Donnelly, J., \& Rickard, K. M. (2015). Meaning in Life and Health: Proactive Health Orientation Links Meaning in Life to Health Variables Among American Undergraduates. Journal of Happiness Studies, 16(3), 583-597. https://doi.org/10.1007/s10902-014-9523-6

Steger, M. F., Frazier, P., Oishi, S., \& Kaler, M. (2006). The meaning in life questionnaire: Assessing the presence of and search for meaning in life. Journal of Counseling Psychology, 53(1), 80-93.

Steger, M. F., Kashdan, T. B., Sullivan, B. A., \& Lorentz, D. (2008). Understanding the Search for Meaning in Life: Personality,
Cognitive Style, and the Dynamic Between Seeking and Experiencing Meaning. Journal of Personality, 76(2), 199-228.

Steger, M. F., Kawabata, Y., Shimai, S., \& Otake, K. (2008). The meaningful life in Japan and the United States: Levels and correlates of meaning in life. Journal of Research in Personality, 42(3), 660-678.

Usman, M. . (2003). Menjadi Guru Profesional. Bandung: Remaja Rosda Karya.

Vaksalla, A., \& Hashimah, I. (2015). How hope, personal growth initiative in meaning in life predict work engagement among nursess in Malaysia private hospitals. International Journal of Arts \& Sciences, 8(2), 321-378.

Widhiastuti, H. (2014). Big Five Personality sebagai Prediktor Kreativitas dalam Meningkatkan Kinerja Angggota Dewan. Jurnal Psikologi, 41(1), 115-133. 